NASA/CR—2006-214239

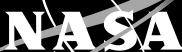

Experimental Validation of a Closed Brayton Cycle System Transient Simulation

Paul K. Johnson and David S. Hervol

Analex Corporation, Brook Park, Ohio 


\section{NASA STI Program . . . in Profile}

Since its founding, NASA has been dedicated to the advancement of aeronautics and space science. The NASA Scientific and Technical Information (STI) program plays a key part in helping NASA maintain this important role.

The NASA STI Program operates under the auspices of the Agency Chief Information Officer. It collects, organizes, provides for archiving, and disseminates NASA's STI. The NASA STI program provides access to the NASA Aeronautics and Space Database and its public interface, the NASA Technical Reports Server, thus providing one of the largest collections of aeronautical and space science STI in the world. Results are published in both non-NASA channels and by NASA in the NASA STI Report Series, which includes the following report types:

- TECHNICAL PUBLICATION. Reports of completed research or a major significant phase of research that present the results of NASA programs and include extensive data or theoretical analysis. Includes compilations of significant scientific and technical data and information deemed to be of continuing reference value. NASA counterpart of peer-reviewed formal professional papers but has less stringent limitations on manuscript length and extent of graphic presentations.

- TECHNICAL MEMORANDUM. Scientific and technical findings that are preliminary or of specialized interest, e.g., quick release reports, working papers, and bibliographies that contain minimal annotation. Does not contain extensive analysis.

- CONTRACTOR REPORT. Scientific and technical findings by NASA-sponsored contractors and grantees.
- CONFERENCE PUBLICATION. Collected papers from scientific and technical conferences, symposia, seminars, or other meetings sponsored or cosponsored by NASA.

- SPECIAL PUBLICATION. Scientific, technical, or historical information from NASA programs, projects, and missions, often concerned with subjects having substantial public interest.

- TECHNICAL TRANSLATION. Englishlanguage translations of foreign scientific and technical material pertinent to NASA's mission.

Specialized services also include creating custom thesauri, building customized databases, organizing and publishing research results.

For more information about the NASA STI program, see the following:

- Access the NASA STI program home page at http://www.sti.nasa.gov

- E-mail your question via the Internet to help@sti.nasa.gov

- Fax your question to the NASA STI Help Desk at 301-621-0134

- Telephone the NASA STI Help Desk at 301-621-0390

- Write to:

NASA STI Help Desk

NASA Center for AeroSpace Information 7121 Standard Drive Hanover, MD 21076-1320 
NASA/CR-2006-214239

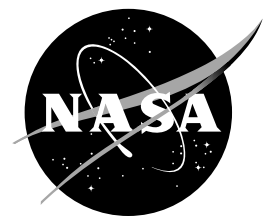

\section{Experimental Validation of a Closed Brayton Cycle System Transient Simulation}

Paul K. Johnson and David S. Hervol

Analex Corporation, Brook Park, Ohio

Prepared for the

Space Technology and Applications International Forum (STAIF-2006)

sponsored by the University of New Mexico's Institute for Space and Nuclear Power Studies (UNM-ISNPS)

Albuquerque, New Mexico, February 12-16, 2006

Prepared under Contract NAS3-00145

National Aeronautics and

Space Administration

Glenn Research Center

Cleveland, Ohio 44135 


\section{Acknowledgments}

The work in this paper was performed for NASA Headquarters, Prometheus Nuclear Systems Program. The authors would like to thank Michael Barrett, Arthur Birchenough, Michael Johnston, and Lee Mason for their assistance with testing and analysis.

This report contains preliminary findings, subject to revision as analysis proceeds.

Level of Review: This material has been technically reviewed by an expert reviewer.

Available from

NASA Center for Aerospace Information 7121 Standard Drive

Hanover, MD 21076-1320
National Technical Information Service 5285 Port Royal Road Springfield, VA 22161 


\title{
Experimental Validation of a Closed Brayton Cycle System Transient Simulation
}

\author{
Paul K. Johnson and David S. Hervol \\ Analex Corporation \\ Brook Park, Ohio 44142
}

\begin{abstract}
The Brayton Power Conversion Unit (BPCU) located at NASA Glenn Research Center (GRC) in Cleveland, Ohio was used to validate the results of a computational code known as Closed Cycle System Simulation (CCSS). Conversion system thermal transient behavior was the focus of this validation. The BPCU was operated at various steady state points and then subjected to transient changes involving shaft rotational speed and thermal energy input. These conditions were then duplicated in CCSS. Validation of the CCSS BPCU model provides confidence in developing future Brayton power system performance predictions, and helps to guide high power Brayton technology development.
\end{abstract}

\section{Introduction}

The Brayton Power Conversion Unit (BPCU) is a closed cycle system using a Helium-Xenon (HeXe) gas working fluid. It was used in previous solar dynamic technology efforts (Shaltens and Mason, 1999) and was modified to its present configuration by replacing the solar receiver with an electrical resistance heater (Hervol, Mason, and Birchenough, 2003). The BPCU was the first closed Brayton cycle to be coupled with an ion propulsion system (Hervol et al., 2004) and was used to examine mechanical dynamic characteristics and responses (Ludwiczak et al., 2005). Model validation of the BPCU thermal transient response was the focus of this work. The BPCU was operated at various steady-state points and then subjected to transient changes involving shaft rotational speed and heat input to provide thermal transient response data. A model representing the BPCU was built using the Closed Cycle System Simulation (CCSS) design and analysis tool. These conditions were then duplicated in CCSS. While similar efforts have modeled terrestrial systems (Traverso, 2005; Wright et al., 2005); the BPCU affords the unique opportunity to model a flight like power conversion system.

\section{Summary of Brayton Power Conversion Unit Thermal Transient Testing}

The BPCU is a fully integrated power conversion system including turbine-alternator-compressor (TAC), recuperator, and gas cooler with a 62.7 mole $\%$ Helium and 37.3 mole $\%$ Xenon $(83.8 \mathrm{~g} / \mathrm{mol})$ working fluid designed for operation up to $2 \mathrm{kWe}$. The heat source used in the test was an annular finned heat exchanger containing a series of silicon-carbide electrical resistance elements that raised the working fluid temperature to over $1000 \mathrm{~K}$, simulating a fission reactor heat source. A commercial chiller with a pumped ethylene glycol cooling loop provided waste heat rejection, simulating a space radiator system. Multi-Foil Insulation (MFI) covered the high temperature components to minimize heat loss in the rough vacuum test environment. The BPCU assembly, the uninsulated electrical resistance heater, and uninsulated recuperator are shown in figure 1. 


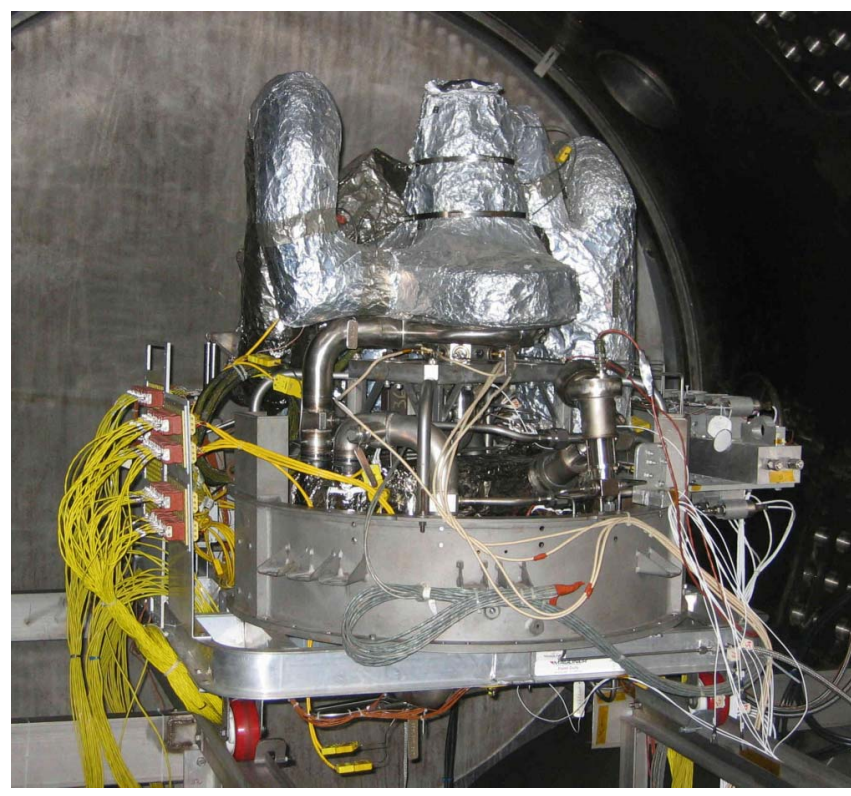

(a) BPCU as installed in Vacuum Facility 6 (VF6).

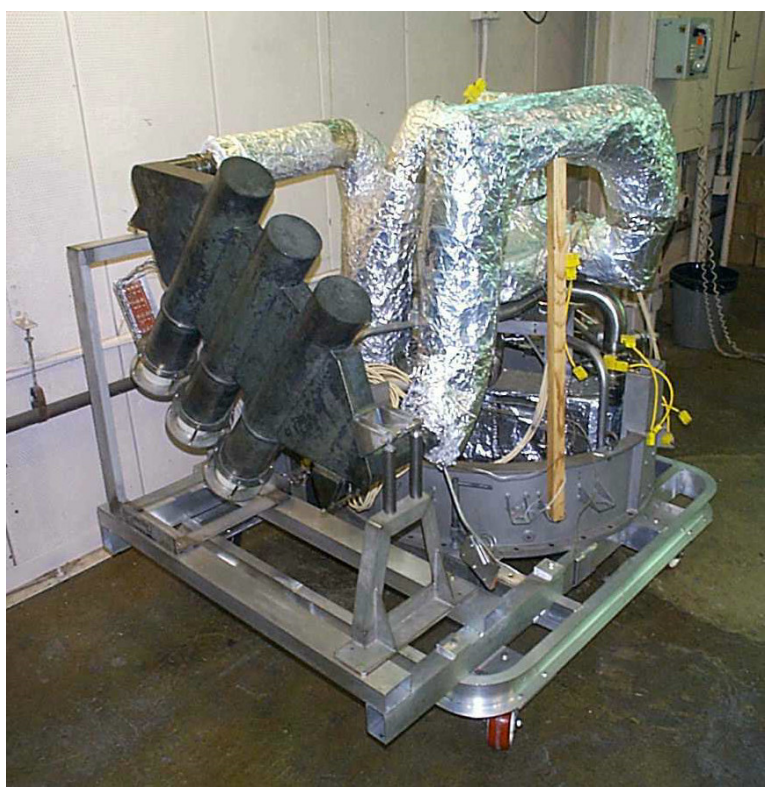

(b) BPCU electrical resistance heater before insulation.

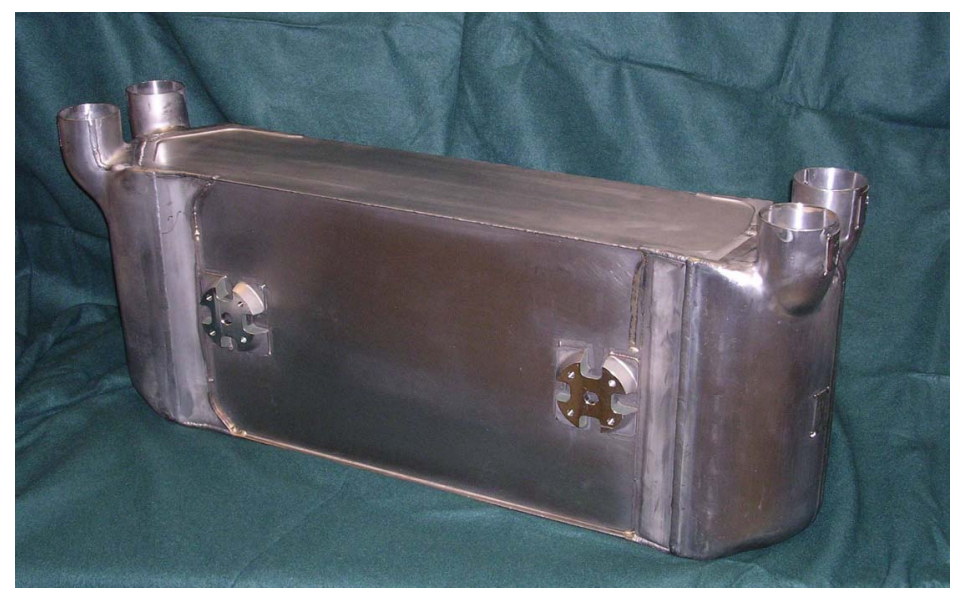

(c) Uninsulated recuperator before BPCU installation.

Figure 1.-BPCU assembly and components.

There are two primary variables used in operating the BPCU: heat input and rotor speed. The BPCU transient thermal test involved 12 transients operating between 7 unique steady-state operating conditions. The first transient data was taken on August 10, 2005. Testing continued until September 20, 2005. The BPCU was operated for about $90 \mathrm{hr}$ total in accomplishing the thermal transient test matrix.

A summary of the thermal transient test matrix is shown in table 1. System steady-state conditions were defined as turbine inlet temperatures changing no more than $9 \mathrm{~K}$ per hr. In some cases, up to $3 \mathrm{hr}$ were required for the system to achieve steady-state temperatures in response to a step change. Later analysis revealed that the main factor in the BPCU thermal response was the heater. Recuperator and ducting mass played a lesser role in system thermal response of the BPCU. The TAC rotational speed response was almost instantaneous. 
TABLE 1.-THE BPCU THERMAL TRANSIENT TEST MATRIX

Positive step change transients

\begin{tabular}{llll}
$\begin{array}{l}\text { Heater power } \\
\text { (kW) }\end{array}$ & $\begin{array}{l}\text { Rotor speed } \\
\text { (kRPM) }\end{array}$ & $\begin{array}{l}\text { Heater power } \\
\text { (kW) }\end{array}$ & $\begin{array}{l}\text { Rotor speed } \\
\text { (kRPM) }\end{array}$ \\
\hline 4 & 28 to 37 & 8 to 6 & 52 \\
4 to 5 & 37 & 6 & 52 to 46 \\
5 & 37 to 46 & 6 to 5 & 46 \\
5 to 6 & 46 & 5 & 46 to 37 \\
6 & 46 to 52 & 5 to 4 & 37 \\
6 to 8 & 52 & 4 & 37 to 28 \\
\hline
\end{tabular}

Results of steady state data are summarized in table 2 . These three test points are shown to represent the practical BPCU operational range. The $37 \mathrm{kRPM}$ and $4 \mathrm{~kW}$ operating condition is near the low end of the compressor, turbine, and alternator performance maps while $52 \mathrm{kRPM}$ and $8 \mathrm{~kW}$ is at the design BPCU operating speed. A middle test point of $46 \mathrm{kRPM}$ and $5 \mathrm{~kW}$ was chosen since it is outside the Brayton blade passing frequency range of 40 to $45 \mathrm{kRPM}$. The average steady-state data from two test matrix iterations is shown along with percent maximum and minimum variation from average.

TABLE 2.-STEADY-STATE DATA FROM SELECTED OPERATING POINTS

\begin{tabular}{|c|c|c|c|c|c|c|}
\hline \multirow[b]{2}{*}{ Location } & \multicolumn{2}{|c|}{37 kRPM 4 kW } & \multicolumn{2}{|c|}{46 kRPM 5 kW } & \multicolumn{2}{|c|}{52 kRPM 8 kW } \\
\hline & Average & $(\% \pm)$ & Average & $(\% \pm)$ & Average & $(\% \pm)$ \\
\hline Heater exit $(\mathrm{K})$ & 913 & $1.20 /-1.65$ & 862 & $2.33 /-2.21$ & 985 & $0.63 /-0.63$ \\
\hline Turbine inlet (K) & 915 & $1.24 / 1.82$ & 865 & $2.55 / 2.43$ & 988 & $0.64 / 0.64$ \\
\hline Turbine exit (K) & 832 & $1.19 / 1.75$ & 766 & $2.49 / 2.36$ & 848 & $0.62 / 0.62$ \\
\hline Recuperator LP inlet $(\mathrm{K})$ & 830 & $1.20 / 1.76$ & 764 & $2.50 / 2.38$ & 846 & $0.63 / 0.63$ \\
\hline Recuperator LP exit (K) & 356 & $0.41 / 0.86$ & 371 & $0.88 / 0.85$ & 396 & $0.21 / 0.21$ \\
\hline Compressor inlet (K) & 285 & $0.06 / 0.09$ & 284 & $0.12 / 0.07$ & 285 & $0.03 / 0.03$ \\
\hline Compressor exit (K) & 330 & $0.14 / 0.20$ & 350 & $0.20 / 0.18$ & 371 & $0.04 / 0.04$ \\
\hline Recuperator HP inlet (K) & 335 & $0.19 / 0.34$ & 355 & $0.35 / 0.31$ & 377 & $0.08 / 0.08$ \\
\hline Recuperator HP exit (K) & 815 & $1.23 / 1.88$ & 751 & $2.63 / 2.53$ & 830 & $0.66 / 0.66$ \\
\hline Heater inlet $(\mathrm{K})$ & 816 & $1.24 / 1.90$ & 751 & $2.64 / 2.55$ & 829 & $0.66 / 0.66$ \\
\hline Compressor inlet $(\mathrm{kPa})$ & 434 & $1.83 / 1.46$ & 393 & $2.16 / 2.58$ & 400 & $0.34 / 0.34$ \\
\hline Compressor exit $(\mathrm{kPa})$ & 552 & $2.05 / 1.46$ & 572 & $2.14 / 2.55$ & 634 & $0.25 / 0.25$ \\
\hline Recuperator HP inlet $(\mathrm{kPa})$ & 552 & $1.92 / 1.47$ & 565 & $2.06 / 2.61$ & 634 & $0.31 / 0.31$ \\
\hline Heater inlet $(\mathrm{kPa})$ & 545 & $1.88 / 1.50$ & 558 & $2.07 / 2.67$ & 627 & $0.33 / 0.33$ \\
\hline Heater exit $(\mathrm{kPa})$ & 545 & $1.91 / 1.44$ & 558 & $2.08 / 2.58$ & 621 & $0.31 / 0.31$ \\
\hline Turbine inlet $(\mathrm{kPa})$ & 545 & $1.90 / 1.48$ & 558 & $2.11 / 2.63$ & 621 & $0.31 / 0.31$ \\
\hline Turbine exit $(\mathrm{kPa})$ & 434 & $1.81 / 1.45$ & 393 & $2.14 / 2.56$ & 400 & $0.34 / 0.34$ \\
\hline
\end{tabular}

For these representative test points, the maximum run to run temperature variation was $2.64 /-2.55$ percent or less and pressure variation was $2.14 /-2.67$ percent or less. The relatively small variation in test data across multiple test runs shows the repeatable nature of the system. This characteristic was important to the model validation since steady-state test points were used to define start and end points for the transient analysis. 


\section{Modeling the BPCU in CCSS}

The Closed Cycle System Simulation is a high fidelity closed-Brayton-cycle design and analysis tool written in the Numerical Propulsion System Simulation (NPSS) modeling environment (Lavelle, Khandelwal, and Owen, 2005). The source code originated from the in-house legacy program Closed Cycle Engine Program (CCEP) (Barrett and Johnson, 2005; Barrett and Reid, 2004; Johnson and Mason, 2005; Klann, 1991). CCSS models all of the major BPCU components (ducts, recuperator, gas cooler, turbine, compressor, alternator, and heater) and accounts for details such as shaft bearing and windage losses and bleed flow paths. A representation of the BPCU system was constructed in CCSS and used to simulate thermal transient response for the purpose of comparing model predictions with actual test data.

\section{System Model}

The CCSS BPCU model can be operated in three different modeling modes: design, off-design, and transient. In design mode, components are sized and cycle state points are specified to meet a desired performance point. In off-design mode, hardware geometries are held fixed from the design case, and shaft rotational speed, gas inventory, heater power, and coolant temperature can be varied to evaluate the system at different steady-state operating points. Transient mode is very similar to off-design mode, with the exception that the duct, recuperator, and heater material temperatures become time-dependent, allowing thermal transients to be evaluated. Each component has a unique set of solver dependent/independent variables that exist in a state of either "on" or "off" depending on the modeling mode. For example, material temperature derivatives are forced to zero for steady-state solutions, but become time-dependent during transient analysis

The flow scheme for the BPCU is typical of a recuperated, closed-Brayton-cycle system with a gascooled alternator. The working fluid is compressed by the compressor and passes over the alternator stator. The high pressure fluid is pre-heated by the recuperator, heated to the cycle maximum temperature by the heater, and expanded by the turbine to produce useful work. The low pressure fluid is pre-cooled by the recuperator and finally cooled to the cycle minimum temperature by the gas cooler. Approximately 2 percent of the flow is diverted from the alternator stator cooling stream to the shaft cavity to provide lubrication and cooling for the gas-foil bearings before being reintroduced to the main flow at the turbine discharge. The individual CCSS components were arranged in a configuration to match the BPCU, as shown in figure 2.

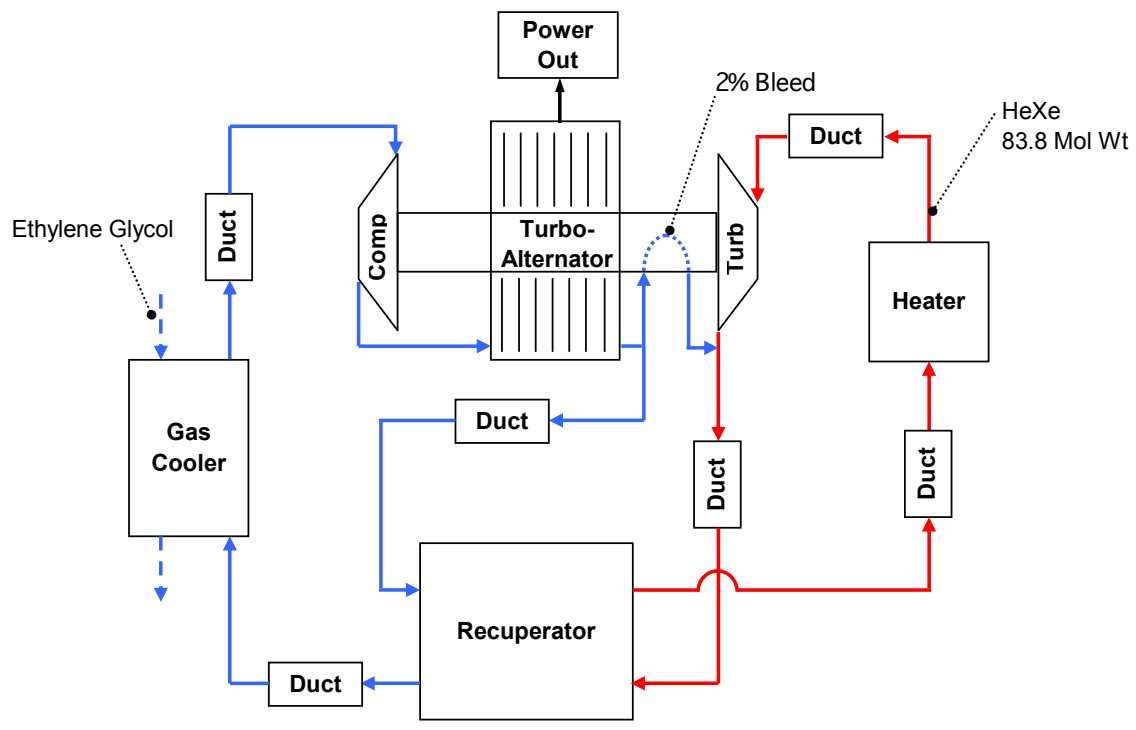

Figure 2.-BPCU CCSS model component configuration. 


\section{Component Models}

Gas ducting is provided for gas flow between the heat exchangers and the TAC. CCSS calculates gas pressure drop and temperature change for each duct. Friction factor and convective heat transfer coefficient are calculated using a Reynolds number correlation for flow through a duct. Radiation heat loss is estimated, assuming perfect vacuum, using the number of foil insulation layers, duct material temperature, and far-field sink temperature. Duct material temperature is modeled with a lumped capacitance method and becomes time-dependent for transient solutions. Equation (1) shows the calculation of the lumped capacitance material temperature time derivative, where $T$ is the component material temperature, $Q$ is the heat transferred into and out of the material, $\mathrm{m}$ is the material mass, and $C$ is the material heat capacity. This equation is used for all components that are modeled in thermal transient mode.

$$
\frac{d T}{d t}=\frac{Q_{\text {in }}-Q_{\text {out }}}{m C}
$$

The gas cooler is a liquid-to-gas, counter-flow, offset strip-fin, stainless steel heat exchanger. Ethylene glycol passes through the liquid side to cool the HeXe to the cycle minimum temperature. Heat transfer correlations and friction factor correlations are used to calculate the heat transfer and pressure drop for each stream. The gas cooler material temperature is not modeled in transient mode because test data shows that the high heat capacity rate of the ethylene glycol keeps the HeXe at a steady exit temperature, regardless of the system operating point.

The heat source heat exchanger consists of three electrical resistance heating elements encapsulated in annular-finned, Haynes 188 metal tubes, and the gas stream flows across the three tubes in series. The heater could not be easily characterized with a fundamentals-based model that accounts for heat losses and multiple material structure temperatures. Therefore, an empirical correlation was formulated from BPCU test data that expresses the convective heat transfer from the heater material to the gas as a function of mass flow rate and viscosity. A lumped capacitance method is used to model material temperature for transient solutions. Relative pressure drop across the heater is expressed empirically as a function of mass flow rate.

The recuperator is a gas-to-gas, counter-flow, offset strip-fin, heat exchanger constructed of Hastelloy X (Killackey, Graves, and Mosinskis, 1978). CCSS uses an approach described by Kays and London to calculate pressure drops and heat transfer in the core and headers (Kays and London, 1964). The core is divided lengthwise into ten nodes and the hot-end and cold-end headers are additional nodes. A lumped capacitance method is employed to model the material temperature of each node. Radiation heat loss for each node is modeled in the same fashion as the duct component described earlier.

The TAC comprises the compressor, turbine, and alternator rotating on a common shaft that is supported by gas-foil thrust and journal bearings. Performance maps are used by CCSS to estimate efficiency and pressure ratio for the turbine and compressor as a function of corrected mass flow rate and percent of design corrected speed (Mock, 1993). The alternator converts shaft power into electric power with an electromagnetic efficiency provided as a function of shaft rotational speed and mechanical shaft power available to the alternator. Windage (viscous drag) loss, thrust bearing loss, and journal bearing loss are estimated as functions of shaft cavity pressure and shaft rotational speed (Mock, 1993). For transient solutions, the TAC is assumed to operate in a quasi-steady-state mode; therefore, shaft dimensions and inertia are not required for transient modeling. When a change in shaft speed is imposed on the model, the shaft instantly attains the new speed. This assumption is valid for BPCU type transient tests because the shaft speed-change time scale is orders of magnitude less than the thermal transient time scale of the system. 


\section{Results and Discussion}

The CCSS BPCU model was operated in both steady-state and transient modes and results were compared to test data. The purpose was not only to compare data, but also to search for areas for improving the model. Unfortunately, some modeling assumptions cannot be fully verified with the current BPCU test setup. For example, the true values of the alternator and bearing losses are not known because they cannot be measured, nor can the bleed flow fraction used for bearing lubrication and cooling be measured. The BPCU design point bleed flow amount is 2.2 percent, but that percentage might change with different engine operating points. The value of 2.2 percent was assumed for all cases in CCSS. For both steady-state and transient modes, the CCSS heater power value was set to match the measured BPCU heater exit temperature. This approach eliminated uncertainties in modeling the convective heat transfer within the heat source heat exchanger and the complex conductive and radiative losses.

\section{Matching Steady-State Data}

The CCSS model was used to simulate three steady-state BPCU operating points. While data for the cases listed in table 2 is the average of multiple runs, CCSS steady-state points were matched to individual BPCU runs. For each case, the CCSS gas inventory was set so that the heater exit pressure matched the test data, and heater power was set so that the heater exit temperature matched the test data. Shaft rotational speed was set to match the BPCU set point and ethylene glycol temperature was set to match the BPCU compressor inlet temperature. Table 3 lists the CCSS results and compares them to corresponding BPCU data.

TABLE 3.-COMPARISON OF BPCU DATA TO CCSS RESULTS FOR THREE STEADY-STATE ENGINE OPERATING POINTS

\begin{tabular}{|c|c|c|c|c|c|c|c|c|c|}
\hline \multirow[b]{2}{*}{ Location } & \multicolumn{3}{|c|}{37 kRPM 4 kW } & \multicolumn{3}{|c|}{46 kRPM 5 kW } & \multicolumn{3}{|c|}{52 kRPM 8 kW } \\
\hline & Data & CCSS & $\%$ Diff & Data & CCSS & $\%$ Diff & Data & CCSS & $\%$ Diff \\
\hline Heater exit* (K) & 913 & 913 & 0.00 & 868 & 868 & 0.00 & 978 & 978 & 0.00 \\
\hline Turbine inlet (K) & 915 & 908 & -0.78 & 871 & 865 & -0.78 & 982 & 974 & -0.84 \\
\hline Turbine exit (K) & 832 & 834 & 0.23 & 772 & 770 & -0.18 & 843 & 843 & 0.06 \\
\hline Compressor inlet* $(\mathrm{K})$ & 285 & 285 & 0.00 & 285 & 285 & 0.00 & 285 & 285 & 0.00 \\
\hline Compressor exit (K) & 330 & 325 & -1.44 & 350 & 341 & -2.73 & 371 & 355 & -4.13 \\
\hline Recuperator HP inlet (K) & 335 & 333 & -0.67 & 355 & 351 & -1.11 & 377 & 368 & -2.26 \\
\hline Heater inlet $(\mathrm{K})$ & 817 & 816 & -0.08 & 758 & 756 & -0.33 & 823 & 826 & 0.32 \\
\hline Heater cylinder $(\mathrm{K})$ & 936 & 937 & 0.09 & 903 & 906 & 0.27 & 1022 & 1016 & -0.57 \\
\hline Heater exit* (kPa) & 552 & 552 & 0.00 & 567 & 567 & 0.00 & 618 & 618 & 0.00 \\
\hline Turbine inlet $(\mathrm{kPa})$ & 554 & 552 & -0.39 & 569 & 567 & -0.39 & 620 & 618 & -0.42 \\
\hline Turbine exit (kPa) & 440 & 440 & 0.09 & 402 & 411 & 2.12 & 400 & 413 & 3.20 \\
\hline Turbine pressure ratio & 1.26 & 1.25 & -0.49 & 1.41 & 1.38 & -2.45 & 1.55 & 1.5 & -3.51 \\
\hline Compressor inlet $(\mathrm{kPa})$ & 439 & 436 & -0.63 & 400 & 406 & 1.30 & 397 & 407 & 2.36 \\
\hline Compressor exit (kPa) & 565 & 556 & -1.46 & 581 & 573 & -1.48 & 635 & 625 & -1.56 \\
\hline Compressor pressure ratio & 1.29 & 1.27 & -0.83 & 1.45 & 1.41 & -2.74 & 1.6 & 1.54 & -3.83 \\
\hline Recuperator HP inlet (kPa) & 562 & 556 & -0.94 & 578 & 572 & -0.91 & 632 & 625 & -1.05 \\
\hline Heater inlet $(\mathrm{kPa})$ & 557 & 555 & -0.39 & 573 & 571 & -0.35 & 627 & 624 & -0.53 \\
\hline Alternator power $(\mathrm{W})$ & 413 & 382 & -7.48 & 507 & 556 & 9.65 & 1141 & 1295 & 13.49 \\
\hline
\end{tabular}


All of the CCSS temperatures were within 1 percent of the data with the exception of the compressor exit temperature and recuperator high pressure (HP) inlet temperature, which were lower than the data by as much as 4.1 percent. This likely a result of the CCSS compressor performance map underestimating pressure ratio and possibly overestimating efficiency. The CCSS turbine exit temperature agreed well with the data, but like the compressor, the pressure ratio was underestimated, particularly at the higher shaft speeds. Alternator power disagreed with the data by as much as 13.5 percent. This was due to the uncertainty in estimating bearing and alternator losses as well as uncertainty in compressor and turbine performance. Compressor and turbine power are very sensitive to pressure ratio. An increase in compressor pressure ratio would result in more power consumed by the compressor, and an increase in turbine pressure ratio would result in more power produced by the turbine. The combination of compressor and turbine performance modeling errors and bearing and alternator loss uncertainties could easily account for the power differences indicated by the data.

\section{Matching Transient Data}

The BPCU system was operated at constant heater electric power and shaft rotational speed set points. Transients were introduced to the system by changing stepwise the heater power and shaft speed set points, and the transient ended when the system reached a new steady-state operating point. The BPCU transients used for comparison had an initial steady-state operating set point of $46 \mathrm{kRPM}$ shaft speed and $6 \mathrm{~kW}$ heater power. The first transient began when the shaft speed set point was increased from 46 to $52 \mathrm{kRPM}$, while the heater power set point remained at $6 \mathrm{~kW}$. Subsequent transients were introduced by changing the heater power set point from 6 to $8 \mathrm{~kW}$, then back to $6 \mathrm{~kW}$, while shaft speed remained at $52 \mathrm{kRPM}$. The fourth and final transient began when the shaft speed set point was reduced from 52 to $46 \mathrm{kRPM}$.

To simulate the BPCU transients, the CCSS model was anchored at the initial steady-state operating point by setting the shaft speed to $46 \mathrm{kRPM}$, adjusting gas mass inventory to match the BPCU heater exit pressure, adjusting heater power to match the heater exit temperature, and adjusting the ethylene glycol temperature to match the compressor inlet temperature. CCSS was then switched to transient mode, and shaft speed and heater power were changed stepwise as appropriate; gas mass inventory and ethylene glycol temperature were held constant for the duration of all four transients. The CCSS heater power set point was manually adjusted at the onset of each transient so that the heater exit temperature matched the BPCU test data at the end of the transient (steady-state point). The process of manually matching the heater exit temperature required a few iterations. An initial guess of heater power was assumed, the transient was simulated, and if the CCSS heater exit temperature was too high, the transient was simulated again with a lower heater power set point. Heater power settings were only changed stepwise at the start of a new transient, never in the middle of a transient. Figure 3 is a comparison plot of heater gas inlet and exit temperatures and recuperator material structure temperature (located midway along the length of the recuperator) data to CCSS results as a function of time for the four consecutive transients. Figure 4 is a comparison plot of alternator power. Vertical dashed lines mark the start of a new transient, and the BPCU shaft speed and heater controller set points are labeled for each case.

One would expect the CCSS heater exit temperature results in Figure 3 to match the steady-state test data points (at time equal to 120, 260, 390, and $480 \mathrm{~min}$ ) because the CCSS heater power was adjusted to do so. However, CCSS was also able to match the shape of the transient curve between the steady-state points for both the heater inlet and heater exit temperatures. The shape of the CCSS recuperator material temperature plot also trends well with the data, which indicates that the lumped capacitance method used to model the recuperator was appropriate. Alternator power was overestimated by CCSS, but the shape of the alternator power transient curve in figure 4 agrees well with the test data. The overestimated power can be traced to the uncertainties in turbine and compressor performance discussed earlier. The shape of the power transient reflects favorably on the behavior of the system temperatures and pressures. Overall, the CCSS transient model proved sufficient for reproducing the time response of the temperatures and power exhibited by the BPCU system. 


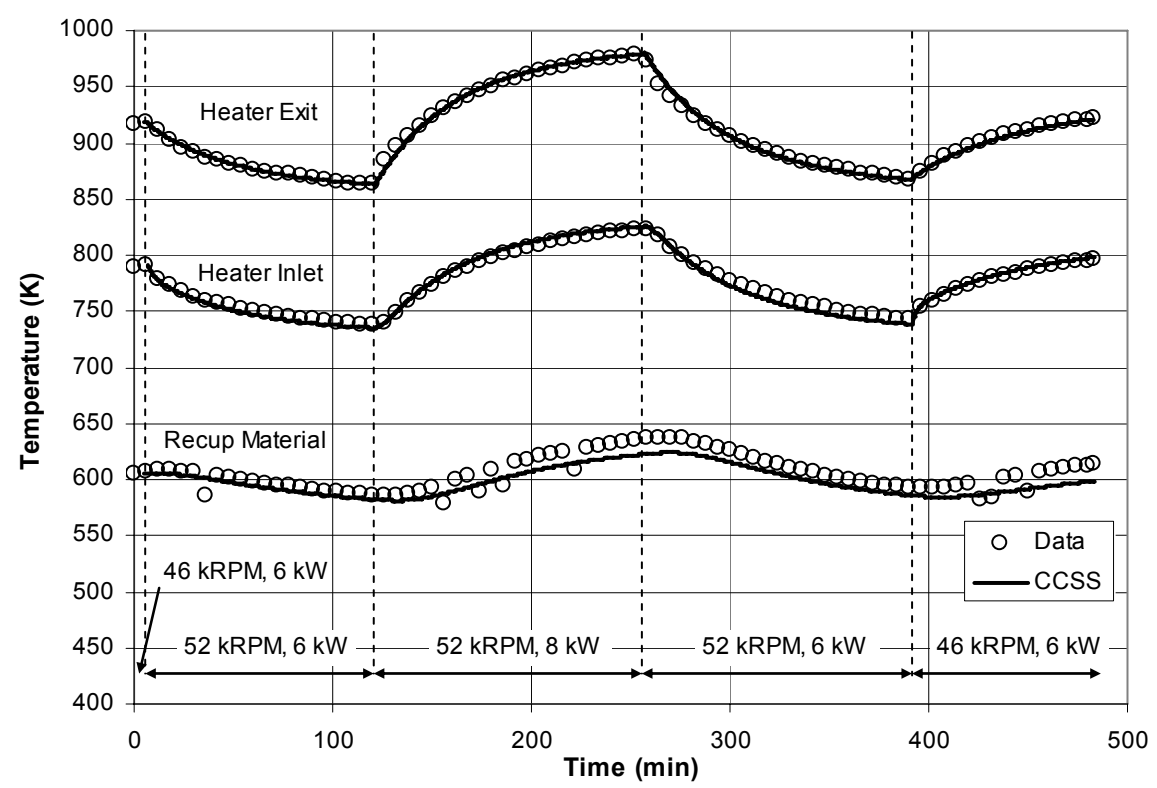

Figure 3.-Comparison of CCSS heater gas temperatures and recuperator material temperature to BPCU test data.

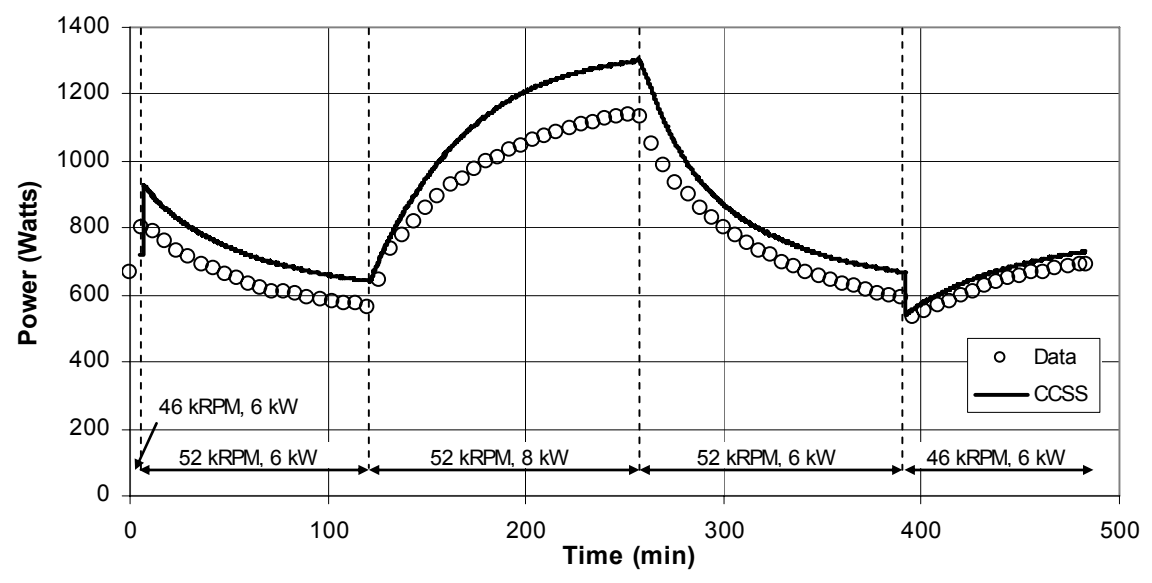

Figure 4.-Comparison of CCSS alternator power to BPCU transient test data.

Three types of CCSS components are included in thermal transient mode (gas ducts, heater, and recuperator). It would be beneficial to know each component's contribution to the overall system transient behavior. One procedure for examining a component's thermal capacitance on a system level is to reduce the other components' thermal capacitance by setting their masses to zero. Figure 5 shows CCSS heater exit temperature results where only one of the three contributing components' mass was considered in the transient analysis at a time and compares the results over two consecutive BPCU transients.

Duct, heater, and recuperator masses are 11,38, and $59 \mathrm{~kg}$, respectively. The CCSS results shown in figure 5 indicate that the gas duct mass contributes very little to the overall system thermal transient, and the heater mass contributes the most. One might conclude that the most massive component would exhibit the longest thermal transient, but despite the recuperator weighing 50 percent more than the heater, a larger heat transfer surface area and higher convective heat transfer coefficient results in a shorter thermal transient time constant for the recuperator than the heater. While component time constants can be evaluated individually, component interdependencies can only be truly assessed when modeled at the system level. 


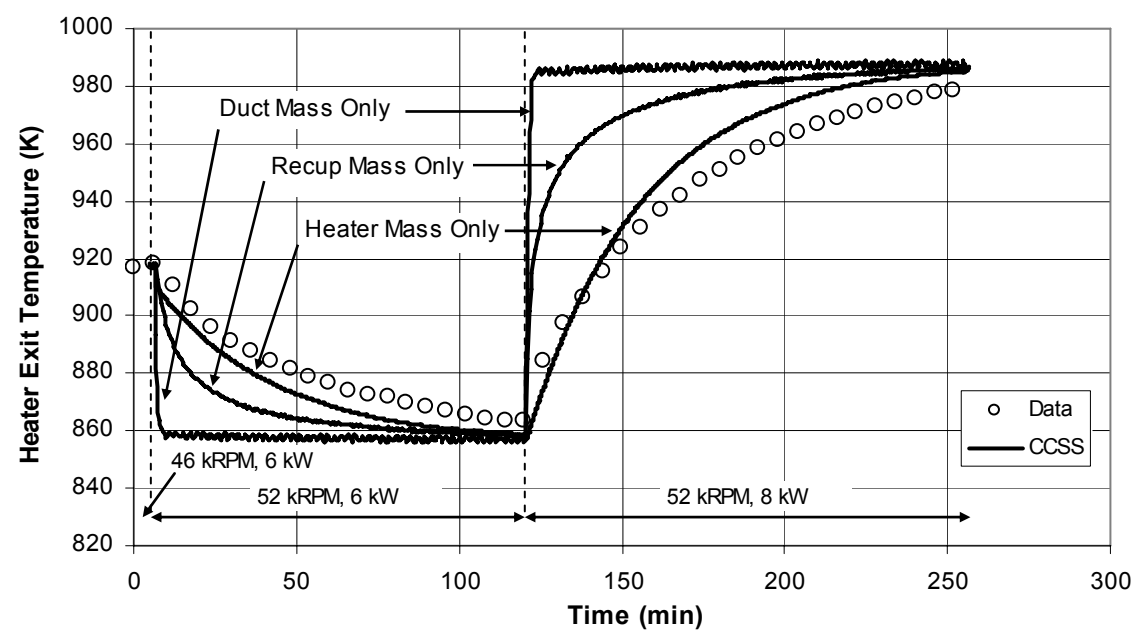

Figure 5.-Component contributions to system thermal transients as modeled by CCSS.

\section{Conclusions}

Testing to date has shown that the BPCU is able to generate meaningful, repeatable data that can be used for computer model validation. The collected data was used to validate a computer model constructed using the CCSS design and analysis code. Results generated by CCSS demonstrated that the model sufficiently reproduced the thermal transients exhibited by the BPCU system. CCSS was also used to match BPCU steady-state operating points. All of the simulated cycle state point temperatures were within 4.1 percent of the data, and most were within 1 percent of the data; cycle pressures were all within 3.2 percent. A larger error (as much as 13.5 percent) in alternator power was attributed to uncertainties in the compressor and turbine maps and alternator and bearing loss models. The acquired understanding of the BPCU behavior gives useful insight for improvements to be made to the CCSS model as well as ideas for future testing and possible system modifications.

\section{References}

Barrett, M.J. and Johnson, P.K., "Performance and Mass Modeling Subtleties in Closed-Brayton-Cycle Space Power Systems," in proceedings of 3rd International Energy Conversion Conference (IECEC2005), AIAA, San Francisco, CA, 2005.

Barrett, M.J. and Reid, B.M., "System Mass Variation and Entropy Generation in 100-kWe ClosedBrayton-Cycle Space Power Systems," in proceedings of Space Technology and Applications International Forum (STAIF-2004), edited by M.S. El-Genk, AIP Conference Proceedings 699, Melville, NY, 2004, pp. 445-452.

Hervol, D.S, Mason, L.S., and Birchenough, A.," Experimental Results From a 2 kW Brayton Power Conversion Unit," in proceedings of Space Technology and Applications International Forum (STAIF-2003), edited by M.S. El-Genk, AIP Conference Proceedings 665, Melville, NY, 2003, pp. 621-628.

Hervol, D.S., Mason, L.S., Birchenough, A., and Pinero, L., "Experimental Investigations from the Operation of a $2 \mathrm{~kW}$ Brayton Power Conversion Unit and a Xenon Ion Thruster," NASA/TM-2004212960, 2004.

Johnson, P.K., and Mason, L.S., "Design and Off-Design Performance of $100 \mathrm{kWe}$-Class Brayton Power Conversion Systems," in proceedings of Space Technology and Applications International Forum 
(STAIF-2005), edited by M.S. El-Genk, AIP Conference Proceedings 746, Melville, NY, 2005, pp. 711-718.

Kays, W.M. and London, A.L., Compact Heat Exchangers, 2nd ed., McGraw-Hill, New York, NY, 1964. Killackey, J.J., Graves, R., and Mosinskis, G., "Design and Fabrication of the Mini-Brayton Recuperator (MBR)," NASA Contractor Report 159429, NASA Lewis Research Center, Cleveland, OH, 1978.

Klann, J.L, Closed Cycle Engine Program Operational Manual, NASA Lewis Research Center, Cleveland, OH, 1991.

Lavelle, T.M., Khandelwal, S.C., Owen, A.K., "Intermediate Fidelity Closed Brayton Cycle Power Conversion Model," in proceedings of 3rd International Energy Conversion Engineering Conference (IECEC 2005), AIAA, San Francisco, CA, 2005.

Ludwiczak, D.R., Le, D.K., McNelis, A.M., Yu, A.C., Samorezov, S., and Hervol, D.S., "Validation of a 2 kWe Closed-Brayton-Cycle Power Conversion System Mechanical Dynamics Model," in proceedings of Space Technology and Applications International Forum (STAIF-2005), edited by M.S. El-Genk, AIP Conference Proceedings 746, Melville, NY, 2005, pp. 750-761.

Mock, T., "Engineering Report: SDGTD (Solar Dynamic Ground Test Demonstrator) Cycle Points," Allied Signal report 41-11460(3) under NASA contract NAS3-26605, Allied Signal Inc. Fluid Systems, Tempe, AZ, 1993.

Shaltens, R.K. and Mason, L.S., "800 Hours of Operational Experience From a 2 kWe Solar Dynamic System," NASA/TM-1999-208840, 1999.

Traverso, A., "TRANSEO Code for the Dynamic Performance Simulation of Micro Gas Turbine Cycles," in proceedings of ASME Turbo Expo 2005, GT2005-68101, ASME, New York, 2005.

Wright, S.A., Lipinski, R.J., Brown, N., Fuller, and R., Nichols, K., "Operational Results of a Closed Brayton Cycle Test-Loop," in proceedings of Space Technology and International Forum (STAIF2005), edited by M. El-Genk, AIP Conference Proceedings 746, Melville, NY, 2005, pp. 711-718. 


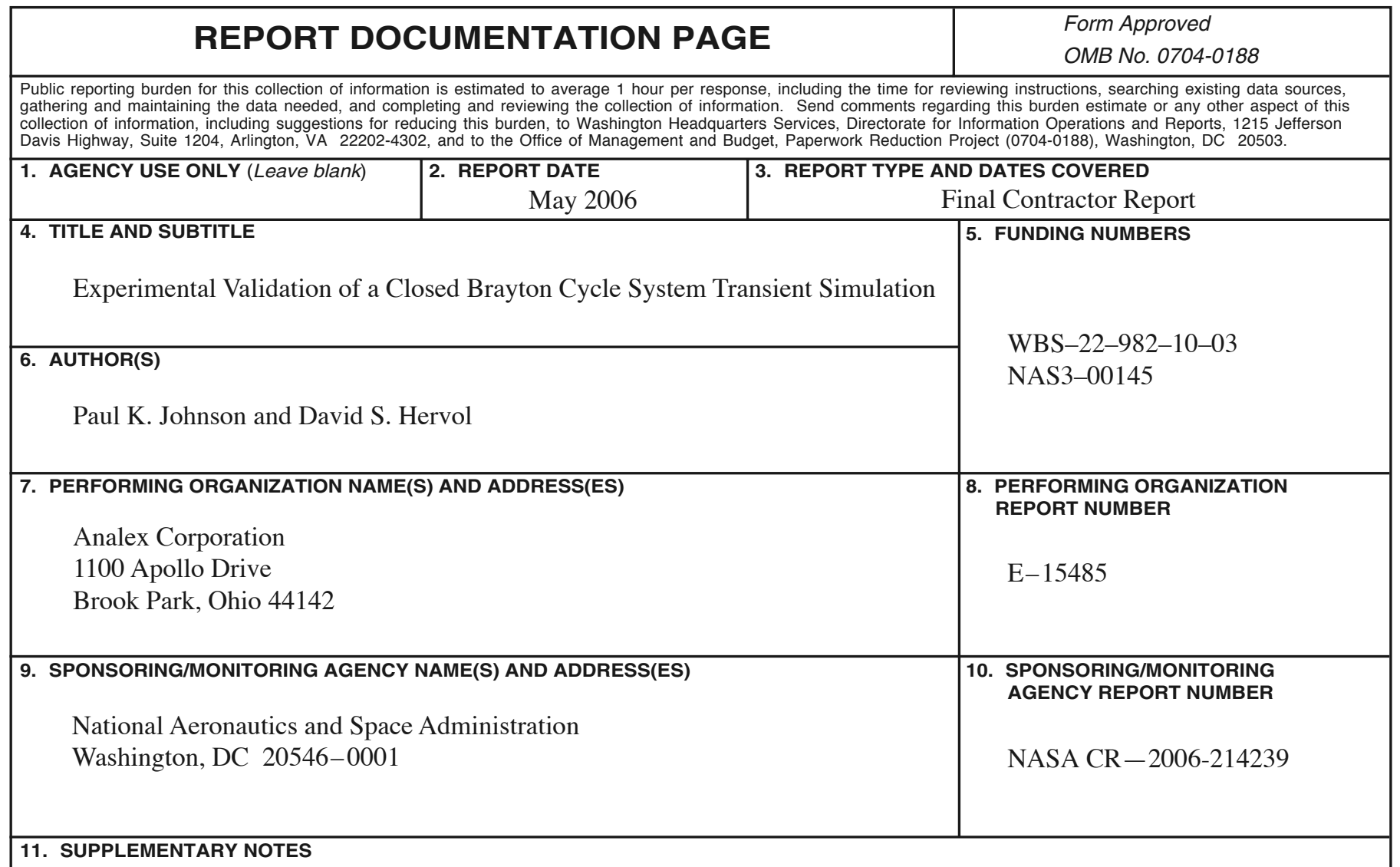

Prepared for the Space Technology and Applications International Forum (STAIF-2006) sponsored by the University of New Mexico's Institute for Space and Nuclear Power Studies (UNM-ISNPS), Albuquerque, New Mexico,

February 12-16, 2006. Project manager, Lee Mason, Power and Electric Propulsion Division, Glenn Research Center, organization code RPT, 216-977-7106.

\begin{tabular}{|l|l|l|l}
\hline 12a. DISTRIBUTION/AVAILABILITY STATEMENT & 12b. DISTRIBUTION CODE
\end{tabular}

Unclassified - Unlimited

Subject Category: 20

Available electronically at http://gltrs.grc.nasa.gov

This publication is available from the NASA Center for AeroSpace Information, 301-621-0390.

13. ABSTRACT (Maximum 200 words)

The Brayton Power Conversion Unit (BPCU) located at NASA Glenn Research Center (GRC) in Cleveland, Ohio was used to validate the results of a computational code known as Closed Cycle System Simulation (CCSS). Conversion system thermal transient behavior was the focus of this validation. The BPCU was operated at various steady state points and then subjected to transient changes involving shaft rotational speed and thermal energy input. These conditions were then duplicated in CCSS. Validation of the CCSS BPCU model provides confidence in developing future Brayton power system performance predictions, and helps to guide high power Brayton technology development.

\begin{tabular}{|c|c|c|c|}
\hline \multicolumn{3}{|l|}{ 14. SUBJECT TERMS } & $\begin{array}{c}\text { 15. NUMBER OF PAGES } \\
16\end{array}$ \\
\hline NSN 7540-01-280-5500 & & & $\begin{array}{l}\text { andard Form } 298 \text { (Rev. 2-89) } \\
\text { scribed by ANSI Std. Z39-18 } \\
3-102\end{array}$ \\
\hline
\end{tabular}



